\title{
Research on the Professional Development Strategies of English Teachers in Higher Vocational Colleges under the Initiative of "the Belt and Road"
}

\author{
Dang Rui-hong
}

Shandong Institute of Commerce and Technology, Jinan, Shandong 250100

Keywords: "the Belt and Road," teacher professional development, strategy

\begin{abstract}
The implementation of "the Belt and Road" has put forward new requirements for China's higher vocational education. Qualified teachers are the guarantee for education quality. Teacher's professional development should be carried out by various methods. The English teachers in higher vocational colleges should actively engage in school-based teaching research and cooperative learning, participate in various academic forums and seek opportunities to participate in international educational exchanges and cooperation to achieve self-improvement.
\end{abstract}

\section{The necessity of professional development for the English teachers in higher vocational colleges from the perspective of "the Belt and Road"}

In 2013, President Xi Jinping put forward "the Belt and Road" Initiative for the first time, aiming at promoting common development by strengthening international cooperation. The Initiative is an important strategy for China to promote its economic and social development and realize the great rejuvenation. The reports of the $19^{\text {th }}$ Party Conference pointed out: China adheres to the Reform and Opening-up policy and actively promotes international cooperation under "the Belt and Road"to create a new platform for international cooperation and common development. Talents are the most important strategic resources to realize national rejuvenation and win international competition. More and more Chinese enterprises are constantly going out, creating an urgent demand for a large number of talents with international vision and expertise, capable of intercultural communication. Due to the differences in social system, customs, history, culture and language etc., there inevitably exist many problems and difficulties in the implementation of "the Belt and Road". Foreign language competence has become a key factor in the economic development, scientific and technological innovation, and international cooperation.

Higher vocational education, as the main fostering place of high-level skilled talents, provides intelligence guarantee and talent reserve for the implementation of "the Belt and Road". Higher vocational education should constantly adjust the talents training plan according to the actual requirements of the international talents, renew the educational concepts, teaching methods and teaching contents, to improve the quality of education and provide high-quality personnel for the construction of "the Belt and Road" Initiative. As an important part of the teaching staff of higher vocational education, English teachers in higher vocational colleges shoulder an important historical mission and play a vital role in the process of cultivating intercultural communication talents. Therefore, English teachers in higher vocational colleges should actively carry out their own professional development, improve their professional knowledge, renew their teaching ideas and adjust their teaching methods and contents so as to make their contributions to the cultivation of qualified talents capable of intercultural communication .

\section{Probe into the possible strategies of English teachers' professional development in higher vocational colleges}

The English teachers in higher vocational colleges should attach more importance to their professional development, give full play to their subjective initiative, and seek every opportunity to improve their professional level and scientific research ability. Only by continuous learning, reflective thinking and innovation can the English teaching staff satisfy the requirements of 
educational reform of the new times.

First of all ,through school-based teaching research and cooperative learning, actively improve their professional capacity. School-based teaching and research is based on the school, to find,study and solve problems in the process of teaching in order to achieve effective teaching and improve the quality of teaching. Higher vocational English teachers have a heavy teaching task and few opportunities to leave teaching posts for further study. They can only make good use of existing resources to carry out teaching and research work. Through reflective teaching, they can constantly improve their own knowledge structure and teaching methods, and improve their professional ability and teaching level. Cooperative learning is also one of the effective ways of professional development for English teachers in higher vocational colleges. Through peer cooperation, cooperation among English teachers as well as professional teachers, it is beneficial to build a teaching team that knows both language and specialty, which is conducive to the realization of the goal of international talent training.

Secondly, English teachers should actively participate in the teaching capacity contest to promote their professional accomplishments. Participating in the teaching capacity contest is one of the effective ways for teachers to improve their self-teaching ability. Through the contest, they can have a deeper understanding of the new teaching concepts and methods. Through the selection of teaching contents, the design of teaching plans, the application of teaching methods and the innovation of teaching means, they can realize effective teaching in reflection and innovation and improve their teaching ability. At present, schools and government's education departments attach great importance to the teaching capacity contest. They organize various teaching contests to encourage teachers to actively participate. Moreover, many schools have included the results of teaching contest in the evaluation of teachers' professional titles and year-end assessment, which greatly stimulates teachers' enthusiasm for participating in the contest and plays a very good role in promoting teachers 'professional development.

Thirdly, English teachers should actively participate in various academic forums, public lectures and short-term research training, actively involve themselves in the exchanges and cooperation between schools, and strive to promote teachers' professional development. Academic forums and public lectures are the relatively economical and practical ways for social education. They have multiple functions such as disseminating frontier ideas, sharing advanced experience and cultivating innovative consciousness. They play an important role in promoting multicultural cooperation and exchange. Under the background of "the Belt and Road", the forum of University Teachers' Development can undoubtedly meet the demands of teachers' professional development. Short-term research training is another effective way to achieve professional development for English teachers in higher vocational colleges. In the spare time of winter and summer vacation, the teachers can take part in short-term research training for one or two weeks. Through the short-term training, the teachers can improve their scientific research ability, renew our teaching concept, innovate teaching methods and improve teaching ability.

Finally, with the help of big data, we should actively carry out information-based teaching reform, carry out online sharing course research and development to promote the construction of English subject curriculum, and realize the professional development of teachers. With the continuous development of the Internet technology, information-based teaching reform is also progressing like a raging fire. Using big data and information technology to promote teaching reform and improve teaching quality has attracted the attention of many educators. Every university is spending a lot of time and energy carrying out information-based teaching reform, develop various online courses, and create all-round studying space and abundant materials for students. The three-dimensional learning space provides high-quality online learning resources, hence promotes the realization of students' professional development and personnel training goals. English teachers actively use information-based teaching methods to construct English online open courses, integrate high-quality teaching resources, and use online and offline hybrid teaching mode to carry out English teaching. While improving the quality of English teaching, they have also achieved their own professional development. 


\section{Conclusion}

Professional development of English teachers in higher vocational colleges is the premise and guarantee to promote the reform of English teaching in higher vocational colleges and to achieve the goal of international talent cultivation. Strengthening the professional development of English teachers, promoting the reform of English teaching, and cultivating compound international talents with high language proficiency and professional knowledge are the objective requirements of the development of higher vocational education. The professional development of English teachers in higher vocational colleges has attracted extensive attention of many educators, and has also attracted more and more attention from higher vocational colleges and government educational departments. Through the research, the author hopes to make some contribution to promote the reform of English teaching and cultivate international talents.

\section{Acknowledgment}

Research on the Training of the International Talents and the Construction of English Teaching Staff in Higher Vocational Colleges under the Initiative of "the Belt and Road"(No. 18CWZJ04, from Shandong Social Science Planning Office.

\section{References}

[1] Fishman, B. J. \& Davis, E. A. Teacher Learning Research and the Learning Sciences [A]. Sawyer, R. K. The Cambridge handbook of the Learning Sciences [C]. Cambridge: Cambridge University Press, 2006.

[2] Hunzicker, J. L. Effective professional development for teachers: a checklist [J]. Professional Development in Education, 2011, (2): 177-179.

[3] Jia Aiwu. A Review of Foreign Language Teacher Education and Professional Development [J].Foreign Language Circles. ,2005,(1):61-66.

[4] Mo Jianxue. Study on the professional development of English teachers in inland Higher Vocational Colleges under the background of "the Belt and Road" [J]. Journal of Hunan Science and Engineering University ,2017,(9):131-133.

[5] Yang Shanshan. Research on the cooperative development mode of English teachers' professional development in China ASEAN Universities under the background of "the Belt and Road" [J]. Journal of Yulin Normal University,2017,(3):132-137. 